tracta, quoniam in sanguine animae comparasti illum', representing a Greek reading iv aiparı $\psi_{\chi x} \hat{\eta} s$. The Syriac has: 'If one be thy slave, reckon him as thy brother; and thou shalt not contend with the blood of thy soul.' I must not take up more space by discussing this quotation here; its importance will easily be recognized.

I have now been able to consult photographs of Cod. B, with the result that several additions might be made to the list of textual corrections; but the only ones of importance are : ( $\mathrm{I}$ ) xxxviii 2 the reading of $B$ recorded in note a should be inserted between the second and third words of the line : it is not a variant to the last word, but a word omitted by $\mathrm{H}$; (2) xl 3 the words supplied in the second pair of half-brackets should be removed, as there is no room for them : B reads no more than 'my members in His Odes'.

R. H. C.

\title{
PUBLICATIONS OF THE S.P.C.K.
}

IN the series of Translations of Christian Literature published by the S.P.C.K. we have, of Greek texts, five new volumes, one by Dr Srawley on The Epistles of St Ignatius that is a revised edition of the introduction and translation originally published in 1900 ; one by $\mathrm{Mr} \mathrm{W}$. Metcalfe, the Address to Origen by Gregory Thaumaturgus and Origen's letter of acknowledgement (a reissue, 1920 , of an edition of 1907); and three that break new ground.

I am not clear that it was worth while to publish in this series a translation in extenso of the Address to Origen unless the object was to shew the tedious style of oratory in vogue at the time and Origen's ability to administer a rather sharp snubbing to a pupil. I cannot agree with Mr Metcalfe that the two tracts form 'the best introduction to the study of Origen's writings'. But he has done the tedious work of translation well, and his introduction is good. 'What need for me enlarging' (p. 9r) and 'dependent of' (p. 6r n.) want correcting.

Dr Crafer, whose articles in the Journal (vol. viii pp. 4or ff, $546 \mathrm{ff}$ ) reintroduced Macarius Magnes as 'a neglected apologist' of the fourth century to students of to-day, and set Dr Harnack to work on the subject of the remains of Porphyry contained in the dialogue of Macarius (see the Journal vol. Xv pp. $360,48 \mathrm{r}$ ), now gives us (The Apacriticus of Macarius Magnes, rgrg) a translation and notes with introduction in which, while clearly indicating the uncertainties and the problems that remain to be solved, he very rightly, in my judgement, 
maintains the chief positions he adopted in 1907 and 1914 as against the theses of Di Harnack, who made no attempt to meet the adverse arguments set forth, partly by way of anticipation, by Dr Crafer. As one whose interest in the subject was aroused by Dr Crafer's original investigation, I heartily echo his wish that his translation (a difficult piece of work excellently done) may enlist the interest of many to whom the name of Macarius Magnes has meant nothing.

In Dionysius the Areopagite on the Divine Names and the Mystical Theology (r92o) Dr Sparrow-Simpson edits the posthumous work of Mr C. E. Rolt and in a short preface gives an appreciation of the fine scholarship and character of the author, as well as some caveats called for by his enthusiasm for the subject of his study. To the editor we are also indebted for a useful bibliography and an essay on 'the influence of Dionysius in religious history'. Dionysius is difficult reading : the translation is fluent and frequently fine, and the notes give much help towards understanding what he meant and the system as a whole. Now and again it seems to me that modernizations (usually kept for the notes) make their way into the text; as when (i 4) $\tau \dot{\eta} v \pi \iota \sigma u \pi$ ó

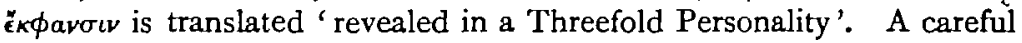
perusal of this volume will enable the many students of theology to place themselves with regard to the writings of the 'Areopagite', and it may increase the number of the elect disciples of the Great Unknown.

A treatise designed to prove the genuineness of these writings of Dionysius is the first entry in the long list of books summarized by Photius in his Bibliotheca, a translation of which, by $\mathrm{Mr}$ J. H. Freese, in five volumes, with a sixth devoted to his life and introduction in general, the S.P.C.K. have been bold enough to undertake, the first volume being now published (The Library of Photius (1920)). Mr Freese's chief aim has been to provide 'a somewhat free translation intended to give the ordinary reader an idea of the literary activity of the chief representative of the so-called Byzantine Renaissance', but he adds valuable notes about the less-known authors and other persons mentioned.

Of the two last-mentioned books the S.P.C.K. itself provides reviews by two experts, Mr A. E. Taylor and Prof. J. B. Bury respectively, in its new monthly journal Theology (vol. i, no. 3) edited by Mr E. G. Selwyn -a journal which promises to have a useful and distinguished career.

Translations by Dr Souter of three of Tertullian's tracts (Concerning Prayer and Concerning Baptism, and Against Praxeas) will be of more value to younger students, and the latter volume in particular because of its special importance and difficulty. It would be rash for any one to question Dr Souter's translations on grounds of latinity, but where early Eucharistic doctrine is involved the greatest linguistic expert may 
go wrong (see Concerning Prayer $\S 6$, where the theologians quoted in the note are better guides to the meaning), and the adversus Praxean sometimes defies translation. Dr Souter gives very valuable help in text and notes and introduction.

The treatise of Novatian on the Trinity by Herbert Moore, M.A., is another volume of the series 'Latin Texts', in which a more paraphrastic method of translation is sometimes adopted, with, I think, excellent results. The short Introduction calls attention to the points of special interest in the treatise.

A third series of these 'Translations of Christian Literature', devoted to 'Liturgical Texts', has already two volumes of importanceSt Ambrose 'On the Mysteries' and the treatise On the Sacraments and The Pilgrimage of Etheria. The translations are the work mainly of the Rev. T. Thompson and Mrs McClure, respectively; neither of whom lived to complete the work. The former volume has been completed by Mr F. H. Colson and Dr Srawley, and the latter by Dr Feltoe. All these names are guarantees of the excellence of the editions, both of which are of high value.

One volume in the series of translations of 'Oriental Texts' calls for special attention-Dr Armitage Robinson's St Irenaeus : the Demonstration of the Apostolic Preaching. It replaces the German translation in which the treatise was first (in 1907) made known from its Armenian version, the French of M. Barthoulot which M. Tixeront edited for Recherches de Science Religieuse (October-December I9r6), and for general use the English translation published last year in the Patrologia Orientalis (which Dr Robinson describes as less accurate than the French).

This new edition makes for the first time widely accessible to English readers a 'handbook of Christian Evidence . . . as it presented itself to a master mind at the end of the second century'. When such a man as Irenaeus sets himself to furmish an absent friend with a summary statement of the Apostolic message and the reasons for believing it in terms of his own day, as Dr Robinson says, he deserves our close attention. The introduction and the notes that are provided give the direction that is needed. But the volume is of special value also to students of Patristics and of the history of Doctrine because of a chapter on 'the debt of Irenaeus to Justin Martyr' and a long essay on 'the doctrine of the Holy Spirit in Justin and Irenaeus' which is of wider scope and interest than its title at first sight suggests and gives prominence to some aspects of the developement of Doctrine which are not always recognized. It is to be noted, too, that here and there the Armenian MS, which also contains a version of books iv and $v$ of the 
treatise Against Heresies utilized by Dr Robinson, helps to restore the meaning of passages extant only in Latin.

In Documents illustrative of the history of the Church to A.D. 313 edited by B. J. Kidd, D.D., we have a collection of extracts which will enable students who cannot read Greek or Latin to feel that they are actually face to face with many of the 'documents' on which knowledge of Christian life and thought during the first three centuries depends. Yet I cannot but regret that these 225 extracts and 278 pages of close print were not arranged under subjects instead of chronologically under authors. The index, in which some subjects as well as names are given, only partially supplies what I think is wanted. A superficial study of it reveals a few omissions. Thus, the first extract is on 'Demons'. I miss the highly instructive passages from Josephus on the expulsion of a demon, and from Justin on their parodies of the Christian sacraments (though Apol. I v is cited). But Dr Kidd has ranged far and wide for his extracts, and there is no collection that covers so much ground, some of it only quite recently accessible (cf. e.g. the Sayings of Paul of Samosata J.T.S. xix 20 ff). Students and teachers of the early History of the Church will find the book most valuable.

Of yet another series entitled 'Handbooks of Christian Literature' there are three volumes to be chronicled.

The Early Christian Books by W. J. Ferrar, M.A., supplies a short introduction to 'Christian literature to the middle of the second century ' outside the New Testament. It aims simply at reproducing 'the opinions of the best scholars' and will, no doubt, be useful ; but-as Mr Ferrar recognizes in his text-it includes some writings that make the sub-title misleading, and-for example-Dom Connolly is not included among 'the best scholars' whose opinions as to the Odes of Solomon are reproduced.

Dr Sparrow-Simpson is to be congratulated on the happy thought which prompted his book The Letiers of St Augustine and the excellent 'way in which he has carried it out. He has worked through all the letters of Augustine, arranged them in groups (prior to his consecration, on Paganism, on the doctrine of God, on African Church divisions, on the doctrine of Grace, on Biblical exposition, to St Jerome, to women, on the Eucharist, on diocesan affairs, the closing years), and summarized the letters of each group with occasional verbatim extracts and a running commentary stringing the letters together and filling up the historical background and the chronological gaps between them. This is a new and very interesting method of presenting the life and thought and activities of a great bishop and divine, and readers of the book will 
appreciate the fresh and personal touch and may acquire much knowledge of Church history and theology in a living and attractive form. It would be a further service to students if to the index of Subjects was added an index of the Letters with the pages on which they arc dealt with.

Books on The Inspiration and Authority of Holy Scripture are already numerous, though the twentieth century still needs one based on premisses other than those that have prevailed in the past. But there is, perhaps, still room for the volume with this title by G. D. Barry, B.D., which is described as 'a study in the literature of the first five centuries', and gives an excellent account of the attitude of Philo and Josephus to the Old Testament and of the chief Christian writers of the period to the Christian Bible in its parts and as a whole.

Most of these books deserve a large circulation, but how can the students who need them most pay $7 s$. $6 d$. for the volume of Documents and Ios. $6 d$. for The Letters of St Augustine? Let the libraries at any rate get them.

There have been good single-volume commentaries and other aids to the study of the Bible before, but Peake's Commentary on the Bible (T. C. \& E. C. Jack, I919), published at the remarkably low price of half a guinea, should now supersede them all, at any rate so far as concerns present knowledge of the historical setting of the books and accurate interpretation of the text, through which alone, as the editor claims, 'the sound basis for devotional use and practical application can be laid'. The ideal which Dr Peake set before himself and expounds in his Preface to the volume is a very high one. $\mathrm{He}$ gathered together a company of contributors who shared the same ideal and have realized it in their work with a degree of unity of achievement on which both they and the editor are to be warmly congratulated. I do not think there can be any doubt that it is the best book of its kind.

I should say the same of $A$ Book about the English Bible by J. H. Penniman, Ph.D., LL.D. (The Macmillan Company, New York, I9 I9), as a popular and very readable account, based on the best sources of information, of the Bible as a whole-not, as the title seems to imply, the English versions only, though the last quarter of the book (roo pages) is occupied with these. The author is Professor of English Literature in the University of Pennsylvania, and it is something like 'all about the Bible' that he set himself as the subject of a series of lectures to his students. So it is chiefly the literary aspects of the collection of books with which he deals. Sources and background, poetic forms, imagery and allusion, Biblical history, Biblical stories, 
parables, prophets, letters and homilies, apocalypses-these are among the headings of his chapters and indicate the method and the form in which a mass of information about the Bible is imparted. The Professor hopes 'that the reader may be sufficiently interested ... to desire to pursue the study further by means of other books' such as are named in the excellent bibliography appended. I think he has done better than this. His lectures must have sent many to the Bible itself with fresh understanding and zest.

The First Three Gospels in Greek, arranged in parallel columns, by Colin Campbell, M.A., D.D. (Oliver \& Boyd, rg18), is described as 'third edition, revised'. It is a synopsis the arrangement of which 'proceeds on the assumption that Mark is not the earliest but the latest of the Synoptic Gospels, the other two having been employed in its composition, whether with or without the aid of a hypothetical document'. The autbor had intended to offer as a prolegomenon a 'demonstration' of this ancient theory, but owing to the difficulties caused by war conditions he has only inserted a few notes in the body of the book 'to indicate some of the lines on which that demonstration would have proceeded'. I have not found in these notes any evidence that Dr Campbell is likely to make many converts to his views. The volume, costing nine shillings, is well printed and easy to handle, and may well be found serviceable by students of other schools.

Of The Subject Index to Periodicals issued by the Library Association (Caxton Hall, Westminster, S.W. r) the volume for I917-1919, A. Theology and Philosophy (including Folk Lore), is now published, price $7 s .6 d$. It contains ${ }_{75}$ large two-column pages, and its system of classification is such that any árticle in the long list of periodicals it surveys (which include The Times and the transactions of learned societies) can readily be traced.

J. F. B-B.

The Ethiopic Liturgy: its sources, development, and present form. By the Rev. Samuel A. B. Mercer, Ph.D. (Munich), Professor of Hebrew and Old Testament, Western Theological Seminary, Chicago: The Hale Lectures, rgr4-1915. (Milwaukee and London, 1915.)

Much has been written recently about the earliest form of the Ethiopic liturgy which has come down to us, little has been written at any time about its successive stages, and nothing (outside the present volume) of its most recent form.

To trace its developement the chief authorities are the edition of the 